\title{
EFFECT OF A NUCLEAR POLYHEDROSIS VIRUS ON Spodoptera frugiperda (SMITH) (LEPIDOPTERA: NOCTUIDAE) LARVAE, ITS DAMAGE AND YIELD OF MAIZE CROP
}

\author{
IVAN CRUZ", EDIRLENE PEREIRA GONÇALVES², MARIA DE LOURDES CORRÊA \\ FIGUEIREDO $^{2}$
}

\author{
${ }^{1}$ Pesquisador, Embrapa Milho e Sorgo. Caixa Postal 151, CEP.35701-970 Sete Lagoas, MG. E-mail: \\ ivancruz@cnpms.embrapa.br (autor paracorrespondência) \\ ${ }^{2}$ Bolsistas $C N P q$.
}

Revista Brasileira de Milho e Sorgo, v.1, n.2, p.20-27, 2002

\begin{abstract}
The efficiency of Baculovirus in a wettable powder formulation to control the fall armyworm Spodoptera frugiperda (Smith) was evaluated using variations of the recommended dose of 50 grams per hectare $\left(2.5 \times 10^{11}\right.$ polyhedron inclusion bodies - $\left.\mathrm{PIB} \mathrm{ha}^{-1}\right)$ : 50 or $100 \mathrm{~g} \mathrm{ha}^{-1}$ applied once, and variations of two applications at seven-day intervals, of $25+25,25+50,50+25$ and $50+50 \mathrm{~g} \mathrm{ha}^{-1}$, compared to untreated plots. The treatments were arranged in a randomized complete block design with six replications. Each plant at 6-8 or 810-leaf growth stages, was artificially infested with 10 newly hatched larvae. The virus suspension $\left(300 \mathrm{~L} \mathrm{ha}^{-1}\right)$ was applied 24 hours after larvae infestation using a back-pack-manual sprayer at 40 PSI $\left(2.8 \mathrm{~kg} \mathrm{~cm}^{-2}\right)$ and a regular flat fan nozzle. Larval mortality rate obtained from plots with the application of $50 \mathrm{~g}$ of Baculovirus wettable formulation $\mathrm{ha}^{-1}$, at once $(96.2 \%)$, was significantly higher than that obtained with the application of $25+25 \mathrm{~g} \mathrm{ha}^{-1}(85.3 \%)$ or $25+50$ $\mathrm{g} \mathrm{ha}^{-1}(87.8 \%)$. However, it was lower than that obtained from the other virus treatments, which had no significant difference among them (mean of $99.2 \%$ ). The damage caused by $S$. frugiperda on the leaves of plants of untreated plots (average of 4.5 in an visual scale from 1 to 5) was significantly different from that observed in plots sprayed with virus (1.75 to 2.33). Plants protected with the virus produced significantly higher yield (mean of 7,577 $\mathrm{kg} \mathrm{ha}^{-1}$ ) than plants unprotected $\left(6,140 \mathrm{~kg} \mathrm{ha}^{-1}\right)$, that is, $23.4 \%$ higher.
\end{abstract}

Key words: Insecta, fall armyworm, biological control, Baculovirus, Zea maiz.

\section{EFEITO DO VÍRUS DE POLIEDROSE NUCLEAR SOBRE LARVAS DE Spodoptera frugiperda (SMITH) (LEPIDOPTERA: NOCTUIDAE), SEU DANO E RENDIMENTO DE GRÃOS DA CULTURA DE MILHO}

RESUMO - Foi avaliada a eficiência de uma formulação pó molhável de Baculovirus para o controle de lagartas de Spodoptera frugiperda (Smith), utilizando variações de uma dose padrão de 50 gramas da formulação (concentração de $2,5 \times 10^{11}$ corpos de inclusões poliédricas - CIP ha ${ }^{-1}$ ): 50 ou $100 \mathrm{~g} \mathrm{ha}^{-1}$, aplicadas de uma única vez, e variações de duas aplicações a intervalos de sete dias, de $25+25,25+50,50+25$ e $50+50 \mathrm{~g} \mathrm{ha}^{-1}$, comparado com uma testemunha sem aplicação de vírus. Os tratamentos foram arranjados em blocos ao acaso, com seis repetições. Cada planta nos estádios de 6 a 8 ou 8 a 10 folhas, foi artificialmente infestada com 10 lagartas recém-nascidas. A suspensão de vírus (300 litros ha $\left.{ }^{-1}\right)$ foi aplicada 24 horas após a infestação, utilizando um pulverizador manual costal, com bico leque e na pressão de 40 PSI $\left(2,8 \mathrm{~kg} \mathrm{ha}^{-1}\right)$. A taxa de mortalidade obtida de parcelas com uma única aplicação de 
$50 \mathrm{~g}$ da formulação de Baculovírus $(96,2 \%$ ) foi significativamente maior que aquela obtida com a aplicação de $25+25 \mathrm{~g} \mathrm{ha}^{-1}(85,3 \%)$ ou $25+50 \mathrm{~g} \mathrm{ha}^{-1}(87,7 \%)$. Entretanto, ela foi menor do que aquela obtida nas outras parcelas tratadas com o vírus nas doses de 50+50 e $100 \mathrm{~g} \mathrm{ha}^{-1}$. Nessas duas parcelas, não se obteve diferença significativa entre as médias de mortalidade, que foi de $99,2 \%$. O dano causado pela $S$. frugiperda nas folhas de plantas nas parcelas testemunhas (média de 4,5 numa escala visual de 1 a 5) foi significativamente diferente daquele observado em parcelas pulverizadas com o vírus $(1,75$ a 2,33$)$. Plantas que receberam aplicações do vírus tiveram maior rendimento (média de $7.577 \mathrm{~kg} \mathrm{ha}^{-1}$ ) que plantas sem proteção (6.140 $\left.\mathrm{kg} \mathrm{ha}^{-1}\right)$, ou seja, $23,4 \%$ a mais.

Palavras-chave: Insecta, lagarta-do-cartucho, controle biológico, Baculovírus, Zea maiz.

The fall armyworm, Spodoptera frugiperda (Smith) is a serious pest of corn in the Americas. It feeds on all growth stages of corn but most frequently in the whorl of young plants. First instar larvae usually eat the green tissue from one side of the leaf leaving the membranous epidermis in the other side intact. Older instars make holes in the leaf and may completely destroy small plants and strip large ones (Cruz, 1995ab). In Brazil, the fall armyworm, $S$. frugiperda is one of the key pests of maize (Zea maiz L.) and other row and vegetable crops (Cruz, 1992, 1995b). Ruppel et al. (1957) stated that the fall armyworm is the most severe pest of corn in Colombia. This is also true in Venezuela (Horovitz, 1960), Peru (Campos, 1968; Pena, 1974), Chile (Etcheverry, 1957), Mexico (Sifuentes, 1967) and the United States of America (Barfield, et al., 1978). According to Lopez-Edwards et al. (1999) the fall armyworm, is a tropical insect species, endemic to the Western Hemisphere, where it ranges from Brazil northward, throughout Central and North America.

Yield reductions due to fall armyworm larvae vary from 17.7 to 57.6 according to the development stage and maize genotypes (Cruz \& Turpin, 1982,1983; Williams \& Davis, 1990; Willink et al., 1991; Cruz et al., 1996, 1999). Control of $S$. frugiperda is based on chemical pesticides, employed when defoliation is noticed in the crop. However, because of the problems associated with the use of pesticides to control this pest, especially the possibility of increasing insecticide resistance level on pest population and reduction of beneficial insects, emphasis has been shifted to biological control (Cruz 1995a; Cruz et al., 1997). Among biological control agents, $S$. frugiperda nuclear polyhedrosis virus (SFNPV) is believed to have great potential to control this pest (Gardner et al. 1984; Moscardi \& Kastelic 1985; Valicente et al., 1989; Valicente \& Cruz, 1991; Hamm et al., 1994, 1997; Valicente \& Costa, 1995; Cruz et al., 1997, Cruz, 2000).

The objective of this study was to evaluate a wettable powder formulation of SFNPV, applied on two different growth stages of maize plants to control S. frugiperda larvae.

\section{Material and Methods}

The experiment was conducted at the Embrapa Maize and Sorghum Research Center, Sete Lagoas, MG, Brazil, during summer, in a dystrophic red latosol soil, under savanna vegetation, using the maize hybrid Pioneer 3041. The treatments were arranged in a randomized complete block design with six replications. The experimental unit consisted of six rows of $8 \mathrm{~m}$ (240 plants). Plants at 6-8 or 8-10leaf growth stages were artificially infested with 10 newly hatched larvae obtained from laboratory culture. A basic wettable power was produced according to Cruz (2000) and applied as an aqueous suspension using a back-pack-manual sprayer at 40 PSI ( $\left.2.8 \mathrm{~kg} \mathrm{~cm}^{-2}\right)$ and a regular flat fan nozzle (Cruz 
\& Santos, 1984). Spraying $\left(3001 \mathrm{ha}^{-1}\right)$ was carried out in the morning, between 08:00 and 10:00 h. The virus was applied 24 hours after larvae infestation, using variation of the standard commercial dose of $50 \mathrm{~g}\left(2.5 \times 11^{11}\right.$ polyhedron inclusion bodies - PIB $\mathrm{ha}^{-1}$ ): 50 or $100 \mathrm{~g}$, applied once, and variations of two applications (at seven-day interval): $25+25$; $25+50 ; 50+25$ and $50+50 \mathrm{~g} \mathrm{ha}^{-1}$, compared to a check plot (untreated control).

Measurements were based on virus efficacy, pest damage and yield. Evaluations on virus efficacy were made in each plot at seven and 10 days after the first virus application by randomly selecting 30 plants plot $^{-1}$ and counting dead and alive larvae. Alive larvae were taken to the laboratory and placed individually in plastic cup with artificial diet. Insects were maintained at $25 \pm 2^{\circ} \mathrm{C}, 70 \% \mathrm{RH}$ and photophase of $12 \mathrm{~h}$, and observed daily, and mortality recorded. Damage evaluations were based on a visual scale (Cruz, 1980) from 1 (no visible damage) to 5 (plant with the whorl destroyed). Plants in each experimental unit in the four central rows were visually rated for leaf damage, 20 days after infestation. At harvest, ears were placed in cloth bags and taken to the laboratory where the damage and the grain weight were taken for each plot. Data on larval mortality, leaf and ear damage and yield were submitted to the analysis of variance and the means were compared using Duncan's multiple range test $(p \leq 0.05)$. Before running analysis of variance, tests were conducted to determine if data set met the necessary assumptions. The Burr-Foster Q-test was used to test equality of variance. For testing the normality of the data, the $\mathrm{W}$ test developed by Shapiro and Wilk was used. Descriptions of both tests are found in Anderson \& McLean (1974). Transformations, when applied, were used according to the criteria suggested by Ostle \& Mensing (1975).

\section{Results and Discussion}

\section{Larval mortality}

In the first evaluation made at the seventh day after the virus application, there was no significant difference in field mortality rate among treatment with virus applied at the 6-8-leaf stage. However, when applied at the 8-10-leaf stage, significantly lower mortality was observed from plots where the virus was applied at $25 \mathrm{~g} \mathrm{ha}^{-1}$ (Table 1). In spite of these differences field mortality was high in all plots with the virus application (57.6 to 71.2\%). The virus lethal period usually is between 6-8 days (Valicente et al . 1989). Therefore, at the seventh day after the application, some larvae were still alive. However, considering the total mortality, that is, adding the field to the laboratory data, the mortality rate increased in all virus treatments. There was no significant difference among treatments where the virus was applied at a minimum dose of $50 \mathrm{~g} \mathrm{ha}^{-1}$. The average mortality rate was 96.2 and $92.3 \%$, at the $6-8$ and 8-10-leaf stages, respectively. Lower mortality was obtained from plots where virus was applied at $25 \mathrm{~g} \mathrm{ha}^{-1}$

In the second evaluation, made three days after the second virus application, field mortality varied from 77.6 to $80.7 \%$ at the 6-8-leaf stage, and from 76.6 to $84.3 \%$ at the $8-10$ leaf stage. As in the first evaluation, there was no significant difference among mortality rates from plots with virus application in the 6-8-leaf stage; at the 8-10-leaf stage, higher mortality was obtained from plots where the virus was initially applied at the dose of $50 \mathrm{~g}$. Finally, considering the total mortality, all the virus treatments, provided at least, $84.1 \%$ mortality (Table 2). One application of $50 \mathrm{~g} \mathrm{ha}^{-1} 24$ hours after infestation, provided a mortality rate of 96.1 and $88.2 \%$, when applied at $6-8$ or 8-10-leaf stage, respectively. Cruz et al. (1997) reported a mortality rate of $90.5 \%$ in evaluation five days after the application of $50 \mathrm{~g} \mathrm{ha}^{-1}$. They found a significant gain 
in efficiency when the virus was applied at a 5-fold concentration. Significant gain was obtained from plots where the virus was applied at the dose of 100 $\mathrm{g} \mathrm{ha}^{-1}$ (2-fold), at once, or applied at seven-day interval, at the doses of $50+25$ (1.5-fold) or 50+50 (2-fold), especially at the 8-10-leaf stage (Table 2).
In both growth stages, significantly lower rate of mortality was obtained from plots where the initial application was $25 \mathrm{~g} \mathrm{ha}^{-1}$, even with a second application of $50 \mathrm{~g}$, seven days later. Apparently, the initial application of $25 \mathrm{~g} \mathrm{ha}^{-1}$ was not enough to provide control rate compared to the other treatments.

TABLE 1. Effect of dose and interval application of SFNPV on the larval mortality of Spodoptera frugiperda (sampled 7 days after first virus application).

\begin{tabular}{|c|c|c|c|c|c|c|}
\hline \multirow{3}{*}{ Dose $\left(\mathrm{g} \mathrm{ha}^{-1}\right)$} & \multicolumn{3}{|c|}{ Field mortality $(\%)^{1}$} & \multicolumn{3}{|c|}{ Total mortality (\%) ${ }^{1}$} \\
\hline & \multicolumn{3}{|c|}{ Leaf stage } & \multicolumn{3}{|c|}{ Leaf stage } \\
\hline & $6-8$ & $8-10$ & Average & $6-8$ & $8-10$ & Average \\
\hline 50 & $66.9 \mathrm{~A}$ & $69.8 \mathrm{~A}$ & $68.4 \mathrm{~A}$ & $95.5 \mathrm{~A}$ & $93.6 \mathrm{~A}$ & $94.6 \mathrm{~A}$ \\
\hline $25+25$ & $63.3 \mathrm{~A}$ & $57.6 \mathrm{~B}$ & $60.5 \mathrm{~B}$ & $81.1 \mathrm{~B}$ & $76.4 \mathrm{~B}$ & $78.8 \mathrm{~B}$ \\
\hline $25+50$ & $60.5 \mathrm{~A}$ & $60.9 \mathrm{~B}$ & $60.7 \mathrm{~B}$ & $79.2 \mathrm{~B}$ & $76.5 \mathrm{~B}$ & $77.8 \mathrm{~B}$ \\
\hline $50+25$ & $67.6 \mathrm{~A}$ & $66.5 \mathrm{~A}$ & $67.1 \mathrm{AB}$ & $95.5 \mathrm{~A}$ & $91.4 \mathrm{~A}$ & $93.5 \mathrm{~A}$ \\
\hline $50+50$ & $71.2 \mathrm{~A}$ & $65.2 \mathrm{~A}$ & $68.2 \mathrm{~A}$ & $97.2 \mathrm{~A}$ & $90.9 \mathrm{~A}$ & $94.1 \mathrm{~A}$ \\
\hline 100 & $67.0 \mathrm{~A}$ & $70.1 \mathrm{~A}$ & $68.5 \mathrm{~A}$ & $96.5 \mathrm{~A}$ & $93.4 \mathrm{~A}$ & $95.0 \mathrm{~A}$ \\
\hline Untreated & $1.2 \mathrm{~B}$ & $1.6 \mathrm{C}$ & $1.4 \mathrm{C}$ & $1.2 \mathrm{C}$ & $3.2 \mathrm{C}$ & $2.2 \mathrm{C}$ \\
\hline Average & $56.8 \mathrm{a}$ & $56.0 \mathrm{a}$ & & $78.0 \mathrm{a}$ & $75.1 \mathrm{a}$ & \\
\hline CV (\%) & 17.4 & 12.4 & 15.0 & 4.95 & 5.21 & 6.2 \\
\hline
\end{tabular}

${ }^{1}$ Means followed by the same capital letter within each column or small letter across each line are not significantly different according to Duncan's multiple range test $(\mathrm{p} \leq 0.05)$.

TABLE 2. Effect of dose and interval application of SFNPV on the larval mortality of Spodoptera frugiperda (sampled 3 days after second virus application).

\begin{tabular}{|c|c|c|c|c|c|c|}
\hline \multirow[t]{3}{*}{ Dose $\left(\mathrm{g} \mathrm{ha}^{-1}\right)$} & \multicolumn{3}{|c|}{ Field mortality (\%) ${ }^{1}$} & \multicolumn{3}{|c|}{ Total mortality $(\%)^{1}$} \\
\hline & \multicolumn{3}{|c|}{ Leaf stage } & \multicolumn{3}{|c|}{ Leaf stage } \\
\hline & $6-8$ & $8-10$ & Average & $6-8$ & $8-10$ & Average \\
\hline 50 & $79.4 \mathrm{~A}$ & $83.7 \mathrm{~A}$ & $81.6 \mathrm{AB}$ & $96.1 \mathrm{~A}$ & $88.2 \mathrm{~B}$ & $92.2 \mathrm{~B}$ \\
\hline $25+25$ & $79.2 \mathrm{~A}$ & $76.6 \mathrm{~B}$ & $77.9 \mathrm{~B}$ & $86.6 \mathrm{~B}$ & $84.1 \mathrm{~B}$ & $85.3 \mathrm{C}$ \\
\hline $25+50$ & $78.8 \mathrm{~A}$ & $80.7 \mathrm{AB}$ & $79.8 \mathrm{AB}$ & $88.5 \mathrm{~B}$ & $87.0 \mathrm{~B}$ & $87.7 \mathrm{C}$ \\
\hline $50+25$ & $77.6 \mathrm{~A}$ & $84.3 \mathrm{~A}$ & $80.9 \mathrm{AB}$ & $100.0 \mathrm{~A}$ & $99.3 \mathrm{~A}$ & $99.6 \mathrm{~A}$ \\
\hline $50+50$ & $80.7 \mathrm{~A}$ & $83.5 \mathrm{~A}$ & $82.1 \mathrm{~A}$ & $100.0 \mathrm{~A}$ & $98.2 \mathrm{~A}$ & $99.1 \mathrm{~A}$ \\
\hline 100 & $80.1 \mathrm{~A}$ & $82.7 \mathrm{~A}$ & $81.4 \mathrm{AB}$ & $99.4 \mathrm{~A}$ & $98.5 \mathrm{~A}$ & $99.0 \mathrm{~A}$ \\
\hline Untreated & $0.0 \mathrm{~B}$ & $1.0 \mathrm{C}$ & $0.5 \mathrm{C}$ & $0.0 \mathrm{C}$ & $1.0 \mathrm{C}$ & $0.5 \mathrm{D}$ \\
\hline Average & $68.0 \mathrm{a}$ & $70.3 \mathrm{a}$ & & $81.5 \mathrm{a}$ & $79.5 \mathrm{~b}$ & \\
\hline CV (\%) & 6.71 & 4.86 & 6.69 & 5.24 & 3.71 & 4.40 \\
\hline
\end{tabular}

${ }^{1}$ Means followed by the same capital letter within each column or small letter across each line are not significantly different according to Duncan's multiple range test $(\mathrm{p} \leq 0.05)$. 
According to the combining analysis considering the two growth stages, there was no significant difference in the total mortality rate obtained from the virus application in the first evaluation (average of 76,5\%). Significant difference existed between growth stages, in the second evaluation. However, the difference was very low (81.5\% at the 6-8 and $79.5 \%$ at the 8 -10-leaf stage) (Table 2). A greater difference was obtained in terms of dose of virus. The total mortality rate obtained from plots with the application of $50 \mathrm{~g} \mathrm{ha}^{-1}$, at once (96.2\%), was significantly higher than that obtained with the application of $25+25 \mathrm{~g} \mathrm{ha}^{-1}(85.3 \%)$ or $25+50 \mathrm{~g} \mathrm{ha}^{-1}(87.8 \%)$. However, it was lower than that obtained from the other virus treatments, which had no significant difference among them (average of $99.2 \%$ ).

\section{Leaf damage}

The damage caused by $S$. frugiperda larvae was severe on the leaves of untreated plots. An average of 4.92 and 4.17 was obtained for infestation at the 6-8 and 8-10-leaf stages, respectively (Table 3). The damage was observed inside the plant whorl, with many plants getting the rate 5 (plants with the whorl destroyed). The damage caused to plants in plots sprayed with virus varied from 1.75 to 2.33 at the 6-8-leaf stage and from 1.83 to 2.33 at the 810-leaf stage. In both cases, lowest damage was verified on plots with one application of $50 \mathrm{~g} \mathrm{ha}^{-1}$, at least. Applications of $25+25$ or $25+50 \mathrm{~g} \mathrm{ha}^{-1}$, at seven-day interval, did not provide the same protection to the plants. However, the leaf damage was significantly lower than that observed from untreated plots. The leaf damage caused by fall armyworm larvae was very close in both growth stage, and there is no interaction between doses of virus and growth stage. However, significant differences existed among doses (Table 3 ).

\section{Ear damage and grain yield}

The damage on ear was very low and confined to the silk and ear tip. Therefore it does not interfere in the results. Significant differences existed among treatments in relation to grain yield (Table 3 ). Plants protected with the virus produced significantly higher yield than plants unprotected. There is no significant difference among the yield obtained from plots where the virus was applied at the initial dose of $50 \mathrm{~g} \mathrm{ha}^{-1}$, in both growth stages (average of $8,056.5 \mathrm{~kg} \mathrm{ha}^{-1}$ at the 6-8-leaf and 7,643.5 $\mathrm{kg} \mathrm{ha}^{-1}$ at the 8-10-leaf stage). These means are, respectively,

TABLE 3. Effect of dose and interval application of SFNPV on the leaf damage caused by Spodoptera frugiperda and on grain yields of maize.

\begin{tabular}{|c|c|c|c|c|c|c|}
\hline \multirow{3}{*}{ Dose $\left(\mathrm{g} \mathrm{ha}^{-1}\right)$} & \multicolumn{3}{|c|}{ Leaf Damage $^{1}$} & \multicolumn{3}{|c|}{ Yield $\left(\mathrm{kg} \mathrm{ha}^{-1}\right)^{1}$} \\
\hline & \multicolumn{3}{|c|}{ Leaf stage } & \multicolumn{3}{|c|}{ Leaf stage } \\
\hline & $6-8$ & $8-10$ & Average & $6-8$ & $8-10$ & Average \\
\hline 50 & $1.83 \mathrm{C}$ & $1.92 \mathrm{BC}$ & $1.87 \mathrm{C}$ & $7.705 \mathrm{AB}$ & $7.642 \mathrm{AB}$ & $7.673 \mathrm{~A}$ \\
\hline $25+25$ & $2.25 \mathrm{~B}$ & $2.33 \mathrm{~B}$ & $2.29 \mathrm{~B}$ & $6.887 \mathrm{C}$ & $6.931 \mathrm{C}$ & $6.909 \mathrm{~B}$ \\
\hline $25+50$ & $2.33 \mathrm{~B}$ & $2.33 \mathrm{~B}$ & $2.33 \mathrm{~B}$ & $7.215 \mathrm{BC}$ & $7.104 \mathrm{BC}$ & $7.159 \mathrm{~B}$ \\
\hline $50+25$ & $2.00 \mathrm{BC}$ & $1.83 \mathrm{BC}$ & $1.92 \mathrm{C}$ & $8.145 \mathrm{~A}$ & $7.579 \mathrm{AB}$ & $7.862 \mathrm{~A}$ \\
\hline $50+50$ & $1.75 \mathrm{C}$ & $1.83 \mathrm{BC}$ & $1.79 \mathrm{C}$ & $8.204 \mathrm{~A}$ & $7.527 \mathrm{AB}$ & $7.865 \mathrm{~A}$ \\
\hline 100 & $1.75 \mathrm{C}$ & $1.67 \mathrm{C}$ & $1.71 \mathrm{C}$ & $8.172 \mathrm{~A}$ & $7.826 \mathrm{~A}$ & $7.999 \mathrm{~A}$ \\
\hline Untreated & $4.92 \mathrm{~A}$ & $4.17 \mathrm{~A}$ & $4.54 \mathrm{~A}$ & $6.166 \mathrm{D}$ & $6.115 \mathrm{D}$ & $6.140 \mathrm{C}$ \\
\hline Average & $2.4 \mathrm{a}$ & $2.3 \mathrm{a}$ & & $7.499 \mathrm{a}$ & $7.246 \mathrm{~b}$ & \\
\hline CV $(\%)$ & 13.8 & 20.3 & 17.23 & 4.1 & 5.0 & 6.57 \\
\hline
\end{tabular}

${ }^{1}$ Means followed by the same capital letter within each column or small letter across each line are not significantly different according to Duncan's multiple range test $(\mathrm{p} \leq 0.05)$. 
$1,890.5$ and $1,528.5 \mathrm{~kg} \mathrm{ha}^{-1}$ higher than the averages obtained from untreated plots. In other words, they represent differences of 30.7 and $25.0 \%$ in yield. Applications of $25+25$ or $25+50 \mathrm{~g} \mathrm{ha}^{-1}$ resulted in similaryields (average of 7,051 and 7,286.5 $\mathrm{kg} \mathrm{ha}^{-1}$, at 6-8 and 8-10-leaf stage, respectively). These yields are 14.3 and $19.1 \%$ higher than those obtained from respective untreated plots.

As in the other parameters, there was interaction between doses and growth stages. However, the average yield was higher in the 6-8leaf stage (difference of $253 \mathrm{~kg} \mathrm{ha}^{-1}$ ), probably due to higher larval mortality obtained in that stage.

Considering the data from the two growth stages (Table 3 ), the grain yield from untreated plots was 6,140 compared with an average of 7,577 $\mathrm{kg} \mathrm{ha}^{-1}$, from the treated plots (difference of $23.4 \%$ ). According to Cruz \& Turpin (1983) maize yield is closely related to fall armyworm leaf damage. Plotting the average leaf damage against yields the functional relationship was quadratic (Figure 1).

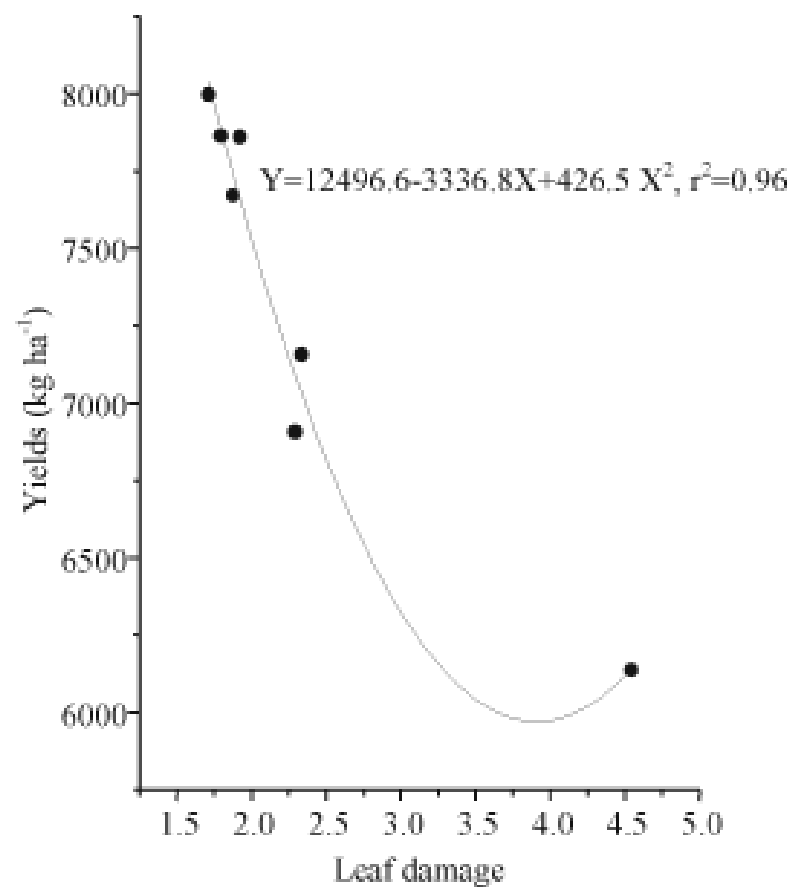

FIGURE 1. Relationship between maize yield and fall armyworm leaf damage from plots protected with different treatment with virus application.
Baculovirus spodoptera formulated as a wettable powder can be used in maize crop for fall armyworm (S. frugiperda) larvae control at the dose of $50 \mathrm{~g} \mathrm{ha}^{-1}\left(2,5 \times 10^{11} \mathrm{PIB} \mathrm{ha}^{-1}\right)$. The use of 50 or $100 \mathrm{~g} \mathrm{ha}^{-1}$, applied 24 hours after infestation, or application at seven-day interval of $50+25$ or $50+50$ $\mathrm{g} \mathrm{ha}^{-1}$, in maize fields, may produce up to $27.8 \%$ higher yield in relation to untreated fields.

\section{References}

ANDERSON, V.L.; McLEAN, R.A. Design of experiments a realistic approach. New York: Marcel Deker, 1974. 418 p.

BARFIELD, C.S.; MITCHELL, E.R.; POE, S.L. A temperature-dependent model for fall armyworm development. Annals of the Entomological Society of America, v.71, p.70-74. 1978.

CAMPOS, P.J. Investigaciones sobre el control biologico del cogollero del maiz Spodoptera frugiperda (J. E. Smith) y otras noctudeos. Revista Peruana de Entomologia, Lima, v.8, p.126131. 1968.

CRUZ, I. Impact of fall armyworm, Spodoptera frugiperda (Smith and Abott 1797) on grain yield in field corn. 1980. 162f. (MSc. Thesis) - Purdue University, West Lafayette, Indiana, USA.

CRUZ, I. Prevenção e controle das pragas de milho e sorgo. In CONGRESSO NACIONAL DE MILHO E SORGO,19, 1992, Porto Alegre. Conferências...Porto Alegre: SAA 1992.p.210233.

CRUZ, I. Manejo integrado de pragas de milho com ênfase para o controle biológico. IN CICLO DE PALESTRAS SOBRE CONTROLE BIOLOGICO DE PRAGAS, 4., 1995. Campinas. Anais ... Campinas: Instituto Agronômico, 1995a. p.48-92.

CRUZ, I. A lagarta-do-cartucho na cultura do milho. Sete Lagoas: Embrapa - CNPMS. 1995b. 45p. (Embrapa - CNPMS, Circular Técnica, 21). 
CRUZ, I. Utilização do Baculovírus no controle da lagarta-do-cartucho do milho, Spodoptera frugiperda. In: MELO, I. S.; AZEVEDO, J. L. (Eds). Controle Biológico. Jaguariúna: Embrapa Meio Ambiente, 2000. v.3, p 201-230.

CRUZ, I.; OLIVEIRA, L.J.; OLIVEIRA, A.C.; VASCONCELOS, C.A. Efeito do nível de saturação de alumínio em solo ácido sobre os danos de Spodoptera frugiperda (J. E. Smith) em milho. Anais da Sociedade Entomológica do Brasil, v.25, p.293-297. 1996.

CRUZ, I.; FIGUEIREDO, M.L.C.; VALICENTE, F.H.; OLIVEIRA, A.C. Application trials with a nuclear polyhedrosis virus to control Spodoptera frugiperda (Smith) on maize. Anais da Sociedade Entomológica do Brasil, Jaboticabal, v.26, p.145152. 1997.

CRUZ, I.; FIGUEIREDO, M.L.C.; OLIVEIRA, A.C.; VASCONCELOS, C.A. Damage of Spodoptera frugiperda (Smith) in different maize genotypes cultivated in soil under three levels of aluminum saturation. International Journal of Pest Management, London, v.45, p.293-296. 1999.

CRUZ, I.; SANTOS, J.P. Diferentes bicos do tipo leque no controle da lagarta do cartucho em milho. Pesquisa Agropecuária Brasileira, Brasília, v.19, p.1-8. 1984.

CRUZ, I.; TURPIN, F.T. Efeito de Spodoptera frugiperda em diferentes estádios de crescimento da cultura de milho. Pesquisa Agropecuária Brasileira, Brasília v.17, p.355-359. 1982.

CRUZ, I.; TURPIN, F.T. Yield impact of larval infestation of the fall armyworm Spodoptera frugiperda (J. E. Smith) to mid-whorl growth stage of corn. Journal of Economic Entomology, College Park, v.76, p.1052-1054. 1983.
ETCHEVERRY, M. Laphygma frugiperda en Chile. Revista Chilena de Entomologia, Santiago, v.5, p.183-192. 1957.

GARDNER, W.A.; NOBLET, R.; SCHWEHR, R.D. The potential of microbial agents in managing populations of the fall armyworm. Florida Entomologist, Gainsville, v.67, p.325-332. 1984.

HAMM, J. J.; CHANDLER, L. D.; SUMNER, H. R. Field tests with a fluorescent brightener to enhance infectivity of fall armyworm (Lepdoptera: Noctuidae) nuclear polyhedrosis virus. Florida Entomologist, Gansville, v.77, n.4, p.425-437, 1994.

HAMM, J. J.; CARPENTER, J. E. Compatibility of nuclear polyhedrosis viruses and inherited sterility for control of corn earworm and fall armyworm (Lepidoptera: Noctuidae). Journal of Entomological Science, Georgia, v.32, n.2, p.148153, 1997.

HOROVITZ, S. Trabajos en marcha sobre resistencia a insectos en el maiz. Agronomia Tropical, Maracay, v.10, p.107-114. 1960.

LOPEZ-EDWARDS, M.; HERNANDEZMENDOZA, J.L.; PESCADOR-RUBIO, A.; MOLINA-OCHOA, J.; LEZAMA-GUTIERREZ, R.; HAMM, J.J., WISEMAN, B.R. Biological differences between five populations of fall armyworm (Lepidoptera: Noctuidae) colected from corn in Mexico. Florida Entomologist, Gainsville, v.82, p.254-262. 1999.

MOSCARDI, F.; KASTELIC, J.G. Ocorrência de vírus de poliedrose nuclear e vírus de granulose em populações de Spodoptera frugiperda atacando soja na região de Sertaneja, PR. In: Embrapa Centro Nacional de Pesquisa da Soja. Resultados de Pesquisa da Soja, 1984/85. Londrina, 1985.p. 128. (EMBRAPA-CNPSO. Documentos, 15. 
OSTLE, B.; MENSING, R.W. Statiscs in research: basic concepts and techniques for research workers. 3: ed. Ames: Iowa State University, 1975. 596p.

PENA, O. N. S. Ensayo sobre control quimico del cogollero del maiz en Tarazoto. Revista Peruana de Entomologia, Lima, v.17, p.123. 1974.

RUPPEL, R.F. Chemical control of the fall armyworm, Laphygma frugiperda in maize in Colombia. FAO. Plant Protection Bulletin, Rome, v.5, p.69-74. 1957.

SIFUENTES A., J.A. Oviposicion de palomillas de cogollero y dano de las larvas en plantulas de maiz y sorgo, en invernadero. Agricultura Tecnica en Mexico, México, v.2, p.311-314. 1967.

VALICENTE, F.H.; COSTA, E.F. Controle da lagarta-do-cartucho, Spodoptera frugiperda (J.E. Smith), com o Baculovirus spodoptera, aplicado via água de irrigação. Anais da Sociedade Entomológica do Brasil, Jaboticabal, v.24, p.6167. 1995.
VALICENTE, F.H.; CRUZ, I. Controle biológico da lagarta-do-cartucho, Spodoptera frugiperda com o Baculovírus. Sete Lagoas: EmbrapaCNPMS,1991.23p. (Embrapa-CNPMS, Circular Técnica 15).

VALICENTE, F.H.; PEIXOTO, M.J.V.V.D.; PAIVA, E.; KITAJIMA, E. Identificação e purificação de um vírus de poliedrose nuclear da lagartado-cartucho, Spodoptera frugiperda. Anais da Sociedade Entomológica do Brasil, Jaboticabal, v.18, p.71-82. 1989.

WILLIAMS, W.P.; DAVIS, F. Response of corn to artificial infestation with fall armyworm and southwestern corn borer larvae. Southwestern Entomologist, Dallas, v.15, p.163-166. 1990.

WILLINK, E.; OSORES, V. M.; COSTILLA, M.A. El gusano cogollero del maiz. Avance Agroindustrial, San Miguel de Tucumau, v.12, p. 3-7, 1991. 